\title{
The blues of P(16)INK(4a): Aberrant promoter methylation and association with colorectal cancer in the Kashmir valley
}

\author{
A. SYED SAMEER ${ }^{1}$, SAFIYA ABDULLAH ${ }^{1}$, SANIYA NISSAR $^{1}$, ROOHI RASOOL ${ }^{1}$, ZAFFAR A. SHAH $^{1}$, \\ DIL AFROZE $^{1}$, NISSAR A. CHOWDRI ${ }^{2}$ and MUSHTAQ A. SIDDIQI ${ }^{1}$
}

Departments of ${ }^{1}$ Immunology and Molecular Medicine, and ${ }^{2}$ General Surgery,

Sher-I-Kashmir Institute of Medical Sciences, Kashmir 190011, India

Received July 29, 2011; Accepted October 24, 2011

DOI: $10.3892 / \mathrm{mmr} .2012 .740$

\begin{abstract}
Hypermethylation of the promoter region of the p16INK4a (p16) gene plays a significant role in the development and progression of colorectal cancer (CRC). The aim of the present study was to establish the role of the methylation status of the $p 16$ gene in $114 \mathrm{CRC}$ cases and to correlate it with the various clinicopathological parameters. Analysis of $p 16$ promoter methylation was performed by methylation-specific PCR. Forty-eight (42.1\%) of the CRC cases were found to be methylated for the $p 16$ gene in our population. The methylation status was found to be associated with the gender, lymph node status, tumour stage, smoking status and tumour grade of the CRC patients. p16 plays a pivotal role in tumour development and progression to advanced stages.
\end{abstract}

\section{Introduction}

Colorectal cancer (CRC) is a major cause of mortality and morbidity, and the third most common malignancy in the world (1). The incidence of this malignancy shows considerable variation among racially or ethnically defined populations in multiracial/ethnic countries. CRC is the third most common type of cancer in men and the second most common cancer in women worldwide (2). Kashmir has been reported as being a high-incidence area of gastrointestinal (GIT) cancers $(3,4)$. In the Kashmir valley, CRC represents the third most common type of GIT cancer, following esophageal and gastric cancer $(5,6)$.

The tumour-suppressor gene pl6INK $4 a$ codes for a cyclin-dependent kinase inhibitor p16INK $4 a$, which acts as a negative regulator of cell growth and proliferation in the G1 phase of the cell cycle $(7,8)$. Functionally, $p 16 I N K 4 a$ has been identified as an inhibitor of cyclin-dependent kinase 4 and 6 . As a consequence, $p 16 I N K 4 a$ plays a significant role in

Correspondence to: Dr Mushtaq A. Siddiqi, Department of Immunology and Molecular Medicine, Sher-I-Kashmir Institute of Medical Sciences, Soura, Srinagar, Kashmir 190011, India

E-mail:mousvi786@gmail.com; vc.tmuk@gmail.com

Key words: p16, colorectal cancer, Kashmir, hypermethylation, methylation-specific polymerase chain reaction, $\mathrm{CpG}$ island the proliferation process of many types of tumour cell growth and apoptosis, and correlates closely with the expression of the proliferating cell nuclear antigen ki67, which is usually viewed as the proliferation marker in intestinal tumours $(9,10)$. Most human colorectal carcinomas show genetic alterations in the pl6INK4a-cyclin D-pRb pathway (11). The p16INK4a gene of the cyclin $\mathrm{D} / \mathrm{pRb}$ pathway has been found to be inactivated in human malignancies with a frequency second only to p53 $(12,13)$. Mutation, homozygous deletions and hypermethylation of the promoter are major mechanisms of p16INK $4 a$ inactivation $(8,14,15)$.

Hypermethylation of non-mutated promoter regions is one of the common mechanisms for inactivating tumoursuppressor genes, which leads to stable allele-specific loss of transcription function (16). Such methylations tend to occur at the sites of $\mathrm{CpG}$ dinucleotides, which are clustered as so-called $\mathrm{CpG}$ islands and are frequently found in promoters of p16INK4a and other tumour-suppressor genes (13). In fact, the major mechanism of $p 16 I N K 4 a$ gene inactivation has been found to be promoter methylation (11). A number of studies have been carried out on $p 16 I N K 4 a$ in different populations, implicating the role of hypermethylation in the development of cancers (17-23). pl6INK4a gene promoter methylation has been observed in colorectal dysplasia, adenomas, malignant tumours and normal mucosa adjacent to tumours $(18,19,24)$.

Two significant investigations were previously carried out in the Kashmir valley in order to establish the role of $p 16 I N K 4 a$ mutations and promoter hypermethylation in gastric and esophageal squamous cell carcinoma, respectively $(13,25)$.

Based on the hypothesis that CRC carcinogenesis is a multi-step and multi-gene event, we designed this study to elucidate the role of $p 16 I N K 4 a$ promoter hypermethylation in the development and progression of CRC in the Kashmiri population and to correlate it with the clinicopathological parameters of CRC cases.

\section{Materials and methods}

Colorectal cancer cases and controls. This study included 114 CRC cases recruited from the Department of Surgery, Sher-I-Kashmir Institute of Medical Sciences (SKIMS), Srinagar, India. Tumour and adjacent normal tissue samples from the cases were resected in the General Surgery Department 
Table I. Primer sequences used in the hypermethylation analysis of the promoter region of the p16 gene.

\begin{tabular}{llcc}
\hline Gene & \multicolumn{1}{c}{ Primer sequence } & $\begin{array}{c}\text { Amplicon size } \\
(\mathrm{bp})\end{array}$ & $\begin{array}{c}\text { Annealing } \\
\text { temperature }\left({ }^{\circ} \mathrm{C}\right)\end{array}$ \\
\hline p16 unmethylation reaction & p16-U1 F: 5'-TTATTAGAGGGTGGGGTGGATTGT-3' & 151 & 70 \\
& $\begin{array}{l}\text { p16-U1 R: 5'-CAACCCCAAACCACAACCATAA-3' } \\
\text { p16-U2 R: 5'-CCACCTAAATCAACCTCCAACCA-3' }\end{array}$ & 234 & 66 \\
p16 methylation reaction & p16-M1 F: 5'-TTATTAGAGGGTGGGGCGGATCGC-3' & 150 & 70 \\
& p16-M1 R: 5'-GACCCCGAACCGCGACCGTAA-3' & & 66 \\
& p16-M2 R: 5'-CCACCTAAATCGACCTCCGACCG-3' & 234 & 66 \\
\hline
\end{tabular}

(SKIMS) and were collected for this study. Data on all CRC cases were obtained from personal interviews with patients and/ or guardians and medical records. All patients and/or guardians were informed of the study and their will to participate in this study was noted in a pre-designed questionnaire (available on request). The mean age of the patients was 52 years.

DNA extraction. Samples were snap-frozen immediately after collection and stored at $-70^{\circ} \mathrm{C}$ until further analysis. DNA was then isolated from both tissue and blood samples using the ammonium acetate method succeeding proteinase-K digestion. The tissue for DNA extraction from the tumour sample was selected by an experienced pathologist and was ascertained to comprise $>90 \%$ tumour cells.

Methylation-specific polymerase chain reaction (MS-PCR) of the p16INK4a promoter. Both normal and tumour DNAs were subjected to sodium bisulphite modification using the EZ DNA Methylation kit (Zymo Research, USA). Approximately $10 \mu 1$ of DNA from each sample was modified as described in the protocol. Previously reported primer sets were used for the amplification of the $p 16$ promoter $(11,26)$. The unmethylated primer pair $p 16-\mathrm{U} 1 \mathrm{~F} / \mathrm{U} 1 \mathrm{R}$ produced an amplicon of $151 \mathrm{bp}$, while $p 16-\mathrm{U} 1 \mathrm{~F} / \mathrm{U} 2 \mathrm{R}$ produced an amplicon $234 \mathrm{bp}$ in length. Similarly, the methylated primer pair $p 16-\mathrm{M} 1 \mathrm{~F} / \mathrm{M} 1 \mathrm{R}$ produced an amplicon of $150 \mathrm{bp}$, while $p 16-\mathrm{M} 1 \mathrm{~F} / \mathrm{M} 2 \mathrm{R}$ produced an amplicon of $234 \mathrm{bp}$ in length. The presence of unmethylation and/or methylation of the $p 16$ promoter was ascertained by the presence of both amplicons.

PCR for both unmethylation as well as methylation detection was performed in a 50- $\mu 1$ total volume reaction mixture containing $10 \mathrm{ng}$ of modified genomic DNA, $100 \mu \mathrm{M}$ of each dNTP, $100 \mathrm{ng}$ of each of the three primers (U1F, U1R and $\mathrm{U} 2 \mathrm{R}$ in the case of unmethylation detection; M1F, M1R and $\mathrm{M} 2 \mathrm{R}$ in the case of methylation detection), $1.5 \mathrm{mM} \mathrm{MgCl}$, $5 \%$ dimethyl sulphoxide (DMSO), 10X Taq buffer and 2 units Taq DNA polymerase (Fermentas, MD, USA). The conditions of PCR were as follows: initial denaturation at $95^{\circ} \mathrm{C}$ for $7 \mathrm{~min}, 40$ cycles of denaturation at $95^{\circ} \mathrm{C}$ for $30 \mathrm{sec}$, annealing at designated temperatures $\left({ }^{\circ} \mathrm{C}\right.$ ) (see Table I) for $45 \mathrm{sec}$ and extension at $72^{\circ} \mathrm{C}$ for $45 \mathrm{sec}$, and final extension at $72^{\circ} \mathrm{C}$ for $10 \mathrm{~min}$ in a Bio-Rad iCycler. The PCR amplicons were electrophoresed on $2.5 \%$ agarose gels and visualised after staining with ethidium bromide.

Universal methylated human DNA (Zymo Research) was used as a positive control for methylated alleles whereas DNA from normal lymphocytes was used as a control for unmethylated alleles. Water was used as a negative PCR control in both reactions.

Statistical analysis. All statistical analyses were performed using PASW software, version 18 (IBM, NY, USA). Pearson's Chi-square two-proportion test was used to evaluate the hypothesis of equal distribution of molecular alterations with different clinicopathological variables. A Fisher's two-tailed test ( $p$-values) of $\leq 0.05$ was considered statistically significant.

\section{Results}

A total of 114 CRC cases were included in this study. The patients comprised 67 males and 47 females (male/female ratio of 1.42). The demographic and clinical characteristics of the CRC cases are shown in Table II. Out of 114 confirmed cases of CRC, 109 cases were sporadic, 4 were familial adenomatous polyposis (FAP) and 1 was Lynch syndrome. All but 1 case were adenocarcinoma and only 1 was squamous cell carcinoma (SCC) of basal cell type; 79 came from a rural and 35 from an urban environment; 49 cases had carcinoma in the colon and 65 in the rectum; 74 were smokers and 40 non-smokers; and 89 cases had well-differentiated adenocarcinoma.

MS-PCR analysis revealed a high methylation status of the pl6INK4a promoter in CRC cases. Forty-eight (42.1\%) of the tumours were found to be hypermethylated at the promoter region of $p 16 I N K 4 a$, while $8(7 \%)$ of the tumours were partially hypermethylated and the remaining $58(50.9 \%)$ of the tumours were not methylated at all (Table II).

Among the 48 patients with tumours which were methylated for the $p 16 I N K 4 a$ gene promoter, 26 were female, 36 had a higher tumour stage $(\mathrm{C}+\mathrm{D}), 38$ were smokers and 31 were of a well-differentiated (WD) grade (Table II).

Statistical analysis between the pl6INK4a hypermethylation status and clinicopathological parameters of the CRC cases revealed a significant association $(\mathrm{p}<0.05)$ with gender (females), lymph node status (present), tumour stage $(\mathrm{C}+\mathrm{D})$, smoking status (smokers) and tumour grade (WD) of the CRC patients (Table II).

\section{Discussion}

This is the first study to report on the association of $p 16$ gene promoter hypermethylation with the risk of development of $\mathrm{CRC}$ in the Kashmiri population. The Kashmir valley, located 
Table II. Comparison between promoter hypermethylation of the $p 16$ gene and clinicopathological variables.

\begin{tabular}{|c|c|c|c|c|}
\hline Variable & Total $(n=114)$ & Methylation $(\mathrm{n}=48 ; 42.1 \%)$ & Non-methylation $(\mathrm{n}=66 ; 57.9 \%)$ & p-value ${ }^{a}$ \\
\hline Age group (years) & & & & 0.330 \\
\hline$\leq 50$ & 45 & 16 & 29 & \\
\hline$>50$ & 69 & 32 & 37 & \\
\hline Gender & & & & 0.020 \\
\hline Male & 67 & 22 & 45 & \\
\hline Female & 47 & 26 & 21 & \\
\hline Dwelling & & & & 1.000 \\
\hline Urban & 35 & 15 & 20 & \\
\hline Rural & 79 & 33 & 46 & \\
\hline Tumour location & & & & 0.560 \\
\hline Colon & 49 & 19 & 30 & \\
\hline Rectum & 65 & 29 & 36 & \\
\hline Nodal status & & & & 0.006 \\
\hline Involved & 68 & 36 & 32 & \\
\hline Not involved & 46 & 12 & 34 & \\
\hline Tumour grade & & & & 0.006 \\
\hline $\mathrm{A}+\mathrm{B}$ & 46 & 12 & 34 & \\
\hline $\mathrm{C}+\mathrm{D}$ & 68 & 36 & 32 & \\
\hline Tumour grade & & & & 0.010 \\
\hline WD & 89 & 31 & 58 & \\
\hline $\mathrm{MD}+\mathrm{PD}$ & 25 & 17 & 8 & \\
\hline Smoking status & & & & 0.009 \\
\hline Positive & 40 & 10 & 30 & \\
\hline Negative & 74 & 38 & 36 & \\
\hline Pesticide exposure & & & & 0.070 \\
\hline Positive & 38 & 11 & 27 & \\
\hline Negative & 76 & 37 & 39 & \\
\hline
\end{tabular}

${ }^{a}$ Fischer's exact two-tailed test. Bold figures indicate statistical significance. WD, well-differentiated; MD, moderately differentiated; PD, poorly differentiated.

in the northern part of India and walled by the Himalayas has a unique ethnic population living in discrete temperate environmental conditions and having unique eating habits, which, along with genetic factors, play a large role in the development of GIT cancers $(4-6,13)$. As previously reported, the etiology and incidence of various GIT cancers in this population has been attributed to a probable exposure to nitroso compounds, amines and nitrates reported to be present in local foodstuffs, such as Hoakhe Suen (sun-dried vegetables), Pharei and Hoggade (sundried and/or smoked fish and meat), Hakh (a leafy vegetable of the Brassica family), hot noon chai (salted tea), dried and pickled vegetables and red chilli, and also through smoking Hukka (a water pipe) $(3,4,27)$.

$\mathrm{CpG}$ island hypermethylation is one of the essential mechanisms of gene inactivation. Cancer cell lines have in general demonstrated an increased frequency of hypermethylation in comparison to primary tumours (28). The inactivation of tumour-suppressor genes by promoter hypermethylation has been recognised to be as common as gene disruption by mutation in tumourigenesis (29-31). A number of studies on CRC around the globe have demonstrated the role of promoter hypermethylation of a number of different genes in the development and progression of CRC (32-34). Promoter hypermethylation of p16INK $4 a$, similarly to that of other genes, plays a pivotal role in the inactivation of $p 16 I N K 4 a$, which in turn enhances tumour development $(11,18,23)$.

In the present study, we observed hypermethylation of the pl6INK4a gene promoter in $42.1 \%$ (48/114) of CRC cases, which is higher than reported by other major studies in the world $(11,20,21)$. However, our observation is consistent with other studies $(22,23)$ which have reported a similar frequency of pl6INK $4 a$ hypermethylation in CRC tumours in the Japanese population. This may be due to the fact that this population is exposed to a special set of environmental challenges, including extreme temperature, high altitude and special food habits, as well as exposure to agricultural by-products, such as pesticides and nitrosamines $(6,13)$. Liang et al, Urosevic et $a l$ and Krtolica et al have already proposed that geographical differences or other unknown factors supplementary to $p 16$ methylation may increase tumour aggressiveness (35-37). 
We found a significant association of the $\mathrm{p} 16 \mathrm{INK} 4 \mathrm{a}$ methylation status with higher Dukes' stage $(\mathrm{C}+\mathrm{D})$. These results are in concordance with those of other studies $(20,21,23)$, which have reported the same observations of a higher methylation status of $p 16 I N K 4 a$ gene promoter with higher Dukes' stage $(\mathrm{C}+\mathrm{D})$. Duke's staging has been considered a most significant prognostic determinant in cancers (20). Dukes' staging, proposed by Dr Cuthbert E. Duke in 1932, is a clinical classification for CRC based on the tumour size, local extent and metastatic status, i.e., lymph node involvement. Hence, the present study supports the observation of Yi et al (20) in suggesting that pl6INK4a methylation may be involved in the malignant transformation of CRC. Furthermore, a significant association was found between pl6INK4a methylation status and lymph node metastasis in our population, as was also reported by Goto et al in their study (23).

We also found that females were more likely than males to have p16INK4a methylated CRC tumours in our population; this supports the study of Wiencke et al (38). They also reported $p 16 I N K 4 a$ methylation to be associated with poorly differentiated tumours. However, contrary to this observation, we found the methylation status of the p16INK4a gene to be associated with a well-differentiated tumour grade. Jie et al previously demonstrated the association of $p 16 I N K 4 a$ methylation status with the proliferative activity of CRC (39). They reported the loss of proliferation and invasion in CRC in tumours with re-expression of $p 16 I N K 4 a$ protein. Thus, epigenetic silencing of pl6INK4a may have a role in driving $\mathrm{CRC}$ tumours to higher differentiation and consequently to invasiveness.

Another unique observation in our study was the association of the methylation status with smoking status. Tumours of the CRC patients who had a history of smoking (cigarettes and/or Hookah) were found to have methylated $p 16 I N K 4 a$ gene promoter $(\mathrm{p}<0.05)$.

In conclusion, in the Kashmir valley population, the high level of epigenetic silencing of p16INK $4 a$ plays a pivotal role in the initial tumourigenesis and also enhances the chances of tumour development and progression to advanced stages.

\section{Acknowledgements}

The authors wish to thank the CRC patients who took part in this study for their cooperation during the interview and sample collection. The authors gratefully acknowledge the financial support provided by the Indian Council of Medical Research (ICMR), New Delhi (5/13/100/2009-NCD-III), for this study and for supporting the fellowship of $\mathrm{Dr}$ A. Syed Sameer as Senior Research Fellow. Thanks are also due to the Head and Technical Staff of the surgical theater of the Department of General Surgery who helped in the tissue procurement, and to the anonymous pathologists of the Department of Pathology for the histopathological assessment of the tumour tissues.

\section{References}

1. Center MM, Jemal A, Smith RA and Ward E: Worldwide variations in colorectal cancer. CA Cancer J Clin 59: 366-378, 2009.

2. Jemal A, Bray F, Center MM, Ferlay J, Ward E and Forman D: Global cancer statistics. CA Cancer J Clin 61: 69-90, 2011.
3. Mir MM, Dar NA, Gochhait S, Zargar SA, Ahangar AG and Bamezai RN: p53 mutation profile of squamous cell carcinomas of the esophagus in Kashmir (India): a high-incidence area. Int J Cancer 116: 62-68, 2005.

4. Murtaza I, Mushtaq D, Margoob MA, Dutt A, Wani NA, Ahmad I and Bhat ML: A study on p53 gene alterations in esophageal squamous cell carcinoma and their correlation to common dietary risk factors among population of the Kashmir Valley. World J Gastroenterol 12: 4033-4037, 2006.

5. Sameer AS, Chowdri NA, Syeed N, Banday MZ, Shah ZA and Siddiqi MA: SMAD4 - molecular gladiator of the TGF-beta signaling is trampled upon by mutational insufficiency in colorectal carcinoma of Kashmiri population: an analysis with relation to KRAS proto-oncogene. BMC Cancer 10: 300, 2010.

6. Sameer AS, Shah ZA, Nissar S, Mudassar S and Siddiqi MA: Risk of colorectal cancer associated with the methylenetetrahydrofolate reductase (MTHFR) C677T polymorphism in the Kashmiri population. Genet Mol Res 10: 1200-1210, 2011.

7. Quelle DE, Zindy F, Ashmun RA and Sherr CJ: Alternative reading frames of the INK4a tumor suppressor gene encode low unrelated proteins capable of inducing cell cycle arrest. Cell 83: 993-1000, 1995.

8. Quelle DE, Cheng M, Ashmun RA and Sherr CJ: Cancer associated mutations at the INK4a locus cancel cell cycle arrest by pl6INK4aINK $4 a$ but not by the alternative reading frame protein p19ARF. Proc Natl Acad Sci USA 94: 669-673, 1997.

9. Berenzi A, Benetti A, Bertalot G, Rodolfi A, Portolani N, Giulini SM, Pulcini G, Vinco A and Tiberio G: Ki67 immunohistochemical evaluation in colorectal cancer and normal colonic mucosa: possible clinical applications. Pathologica 84: 155-163, 1992.

10. Ciaparrone M, Yamamoto H, Yao Y, Sgambato A, Cattoretti G, Tomita N, Monden T, Rotterdam H and Weinstein IB: Localization and expression of p27KIP1 in multistage colorectal carcinogenesis. Cancer Res 58: 114-122, 1998.

11. Herman JG, Merlo A, Mao L, Lapidus RG, Issa JP, Davidson NE, Sidransky D and Baylin SB: Inactivation of the CDKN2/ p16INK4a/MTS1 gene is frequently associated with aberrant DNA methylation in all common human cancers. Cancer Res 55: 4525-4530, 1995.

12. Baylin SB, Herman JG, Graff JR, Vertino PM and Issa JP: Alterations in DNA methylation: a fundamental aspect of neoplasia. Adv Cancer Res 72: 141-196, 1998.

13. Salam I, Hussain S, Mir MM, Dar NA, Abdullah S, Siddiqi MA, Lone RA, Zargar SA, Sharma S, Hedau S, Basir SF, Bharti AC and Das BC: Aberrant promoter methylation and reduced expression of p16INK4a gene in esophageal squamous cell carcinoma from Kashmir valley: a high-risk area. Mol Cell Biochem 332: 51-58, 2009.

14. Haber D: Splicing into senescence: the curious case of $p 16 I N K 4 a$ and p19ARF. Cell 91: 555-558, 1997.

15. Ranade K, Hussussian CJ, Sikorski RS, Varmus HE, Goldstein AM, Tucker MA, Serrano M, Hannon GJ, Beach D and Dracopoli NC: Mutations associated with familial melanoma impair p16INK4aINK4a function. Nat Genet 10: 114-116, 1995.

16. Myohanen SK, Baylin SB and Herman JG: Hypermethylation can selectively silence individual p16INK4aINK4a alleles in neoplasia. Cancer Res 58: 591-593, 1998.

17. Kamb A, Gruis NA, Weaver-Feldhaus J, Liu Q, Harshman K, Tavtigian SV, Stockert E, Day RS III, Johnson BE and Skolnick MH: A cell cycle regulator potentially involved in genesis of many tumor types. Science 264: 436-440, 1994.

18. Rashid A, Shen L, Morris JS, Issa JP and Hamilton SR: Cpg island methylation in colorectal adenomas. Am J Pathol 159: 1129-1135, 2001.

19. Trzeciak L, Hennig E, Kolodziejski J, Nowacki M and Ostrowski J: Mutations, methylation and expression of cdkn2a/ p16INK4a gene in colorectal cancer and normal colonic mucosa. Cancer Lett 163: 17-23, 2001.

20. Yi J, Wang ZW, Cang H, Chen YY, Zhao R, Yu BM and Tang XM: Pl6INK 4a gene methylation in colorectal cancers is associated with Duke's staging. World J Gastroenterol 7: 722-725, 2001.

21. Ishiguro A, Takahata T, Saito M, Yoshiya G, Tamura Y, Sasaki $\mathrm{M}$ and Munakata A: Influence of methylated p15 and p16INK4a genes on clinicopathological features in colorectal cancer. J Gastroenterol Hepatol 21: 1334-1339, 2006.

22. Nakayama H, Hibi K, Taguchi M, Takase T, Yamazaki T, Kasai Y, Ito K, Akiyama S and Nakao A: Molecular detection of p16INK4a promoter methylation in the serum of colorectal cancer patients. Cancer Lett 188: 115-119, 2002. 
23. Goto T, Mizukami H, Shirahata A, Sakata M, Saito M, Ishibashi K, Kigawa G, Nemoto H, Sanada Y and Hibi K: Aberrant methylation of the pl6INK $4 a$ gene is frequently detected in advanced colorectal cancer. Anticancer Res 29: 275-277, 2009.

24. Issa JP, Ahuja N, Toyota M, Bronner MP and Brentnall TA: Accelerated age-related cpg island methylation in ulcerative colitis. Cancer Res 61: 3573-3577, 2001.

25. Bashir SA, Pandith AA, Yousuf A, Parveen N, Siddiqi MA, Muddassar S, Andrabi KI and Abdin MZ: Lack of pl6INK4a gene mutations in gastric cancers in Kashmir. Asian Pac J Cancer Prev 11: 339-342, 2010

26. Herman JG, Graff JR, Myöhänen S, Nelkin BD and Baylin SB Methylation-specific PCR: a novel PCR assay for methylation status of CpG islands. Proc Natl Acad Sci USA 93: 9821-9826, 1996.

27. Siddiqi M, Kumar R, Fazili Z, Spiegelhalder B and Preussmann R: Increased exposure to dietary amines and nitrate in a population at high risk of esophageal and gastric cancer in Kashmir (India). Carcinogenesis 13: 1331-1335, 1992.

28. Paz MF, Fraga MF, Avila S, Guo M, Pollan M, Herman JG and Esteller M: A systematic profile of DNA methylation in human cancer cell lines. Cancer Res 63: 1114-1121, 2003.

29. Esteller $M$ and Herman JG: Cancer as an epigenetic disease: DNA methylation and chromatin alterations in human tumours. J Pathol 196: 1-7, 2002.

30. Karpiński P, Sasiadek MM and Blin N: Aberrant epigenetic patterns in the etiology of gastrointestinal cancers. J Appl Genet 49: 1-10, 2008.

31. Jones PA and Baylin SB: The fundamental role of epigenetic events in cancer. Nat Rev Genet 3: 415-428, 2002.

32. Lind GE, Thorstensen L, Løvig T, Meling GI, Hamelin R, Rognum TO, Esteller M and Lothe RA: CpG island hypermethylation profile of primary colorectal carcinomas and colon cancer cell lines. Mol Cancer 3: 28, 2004.

33. Lee S, Hwang KS, Lee HJ, Kim JS and Kang GH: Aberrant CpG island hypermethylation of multiple genes in colorectal neoplasia. Lab Invest 84: 884-893, 2004.
34. Toyota M, Ahuja N, Ohe-Toyota M, Herman JG, Baylin SB and Issa JP: CpG island methylator phenotype in colorectal cancer. Proc Natl Acad Sci USA 96: 8681-8686, 1999.

35. Liang JT, Chang KJ, Chen JC, Lee CC, Cheng YM, Hsu HC, Wu MS, Wang SM, Lin JT and Cheng AL: Hypermethylation of the $p 16 I N K 4 a$ gene in sporadic T3NOM0 stage colorectal cancers: association with DNA replication error and shorter survival. Oncology 57: 149-156, 1999.

36. Urosevic N, Krtolica K, Skaro-Milic A, Knezevic-Usaj S and Dujic A: Prevalence of G-to-T transversions among K-ras oncogene mutations in human colorectal tumors in Yugoslavia. Int J Cancer 54: 249-254, 1993.

37. Krtolica K, Krajnovic M, Usaj-Knezevic S, Babic D, Jovanovic D and Dimitrijevic B: Comethylation of p16INK4a and MGMT genes in colorectal carcinoma: correlation with clinicopathological features and prognostic value. World J Gastroenterol 13: 1187-1194, 2007

38. Wiencke JK, Zheng S, Lafuente A, Lafuente MJ, Grudzen C, Wrensch MR, Miike R, Ballesta A and Trias M: Aberrant methylation of PI6INK4aINK $4 a$ in anatomic and gender-specific subtypes of sporadic colorectal cancer. Cancer Epidemiol Biomarker Prev 8: 501-506, 1999.

39. Jie G, Zhixiang S, Lei S, Hesheng L and Xiaojun T: Relationship between expression and methylation status of p16INK4aINK4a and the proliferative activity of different areas' tumour cells in human colorectal cancer. Int J Clin Pract 61: 1523-1529, 2007. 